\title{
Familial Transmission of a Chromosomal Translocation $\mathrm{t}(2 \mathrm{q}+; \mathrm{Cp}-)$
}

\section{CARMEN B. LOZZIO and ANTHONY A. KATTINE}

From Birth Defects Evaluation Center, ${ }^{\star}$ University of Tennessee Memorial Research Center and Hospital, Knoxville, Tennessee, U.S.A.

Reciprocal translocations involving duplications of different regions of chromosomes of group C have been reported in patients with multiple congenital malformations. Some of these cases died at 2 or 3 months of age (de Grouchy et al., 1967a, b; Gray et al., 1966). Others were discovered at ages ranging from 12 months to 12 years (Edwards et al., 1962; Rohde and Catz, 1964; de Grouchy and Canet, 1965; Lindsten et al., 1965; Punnett et al., 1966; Lejeune et al., 1966; Lord, Casey, and Laurance, 1967). Each case had different phenotype probably because they represent partial trisomies for different regions of different chromosomes. Therefore, reports of all the new cases and attempts to identify the chromosomes involved will contribute to characterize new syndromes when enough patients with duplications for similar regions of the same chromosome become known.

In this paper, we present a detailed description of the multiple congenital anomalies observed in a stillborn child, who had a duplication for almost all the short arm of one chromosome C (probably No. 8 ) and a small deletion for the long arm of a No. 2. The father of this child was found to be the balanced translocation heterozygote, which may be written $46, \mathrm{XY}, \mathrm{t}(2 \mathrm{q}+; \mathrm{Cp}-)$ according to the nomenclature adopted at the Chicago Conference (1966).

\section{Case Report}

The propositus was the first child of a 27-year-old Negro mother and a 29 -year-old Negro father. Pregnancy was normal. The infant was delivered by caesarean section because of cephalo-pelvic disproportion. At delivery he showed symptoms of respiratory depression. Resuscitation was attempted but the child died. Birthweight was approximately $3.2 \mathrm{~kg}$. Gross examination revealed a flat occiput, mongoloid slanted eyes, an incarcerated right inguinal hernia, and disarticulation of both knees and hips.

External examination of the infant at necropsy revealed meconium over the skin and several prominent deformities. The head had a flat occiput, malformed external

Received July 25, 1968.

$\star$ Aided by a grant (CE-22) from the National Foundation. ears, bilateral palpebral oedema, haemorrhagic sclerae, and submucosal haemorrhage in the lips (Fig. 1a). Theo caput succedaneum was present over the right posteriorios parietal area. The upper extremities were essentially? normal except for the hands, which had abnormalfinger-nails, a palmar simian crease, a single crease of the $\uparrow$ fifth finger, and a high axial triradius (Fig. 1b). The? trunk was normal. However, a bulge due to a rightinguinal hernia was noted. In the lower extremities, ${ }_{\subset}$ both knees had dislocation of the tibia anterior to the condyles of the femur. Both ankles were dislocated $\vec{\bullet}$ laterally (Fig. 1c).

Internal examination of the infant disclosed multiple. petechiae over the surface of the thymus, lungs, and heart. The right lobe of the liver was paler than the left. Thes ductus arteriosus measured $4 \mathrm{~mm}$. in diameter and its intimal surface was wrinkled. The cranial sutures@ had fused and the bone of the skull was calcified. The brain itself had a communicating hydrocephaly (Fig. 1d).

Histological studies showed aspiration of amniotic $\overrightarrow{\vec{B}}$ debris in the lungs, fatty metamorphosis in the right 3 lobe of the liver, focal hepatic necroses, and hyperplasia of the islets of Langerhans.

In review, the multiple deformities of the infant caused protracted labour and death from the resultant? intrauterine anoxia.

Cytogenetic findings. Chromosome analyses were made from blood leucocyte cultures, using a slight modi-윽 fication of the method of Moorhead et al. (1960). The blood for the study of the propositus was obtained 10 응 hours after death by puncture of the heart. Micro- $D$ scopical examination of 75 well-spread metaphases? showed a modal number of 46 chromosomes in 71 cells. Two cells had 45 chromosomes and two had 47 chromo- $\sigma$ somes. All the cells, including those with abnormal $N$ chromosome counts, showed that one chromosome, No. N 2, was unusually long (Fig. 2). The analysis of $13 \mathrm{\omega}$ karyotypes confirmed the difference in the size of chro- $\bar{O}$ mosome No. 2. The two cells with 45 chromosomes 0 presented a random loss of one chromosome of groups $E \underset{\Phi}{\widetilde{D}}$ and G, respectively. The two cells with 47 chromo- $\stackrel{\text { ? }}{?}$ somes showed an extra chromosome similar to those of 7 group D. The abnormal length of one of the No. 2 chromosomes suggested the possibility of this chromo- $\mathbb{D}$ some being one product of a reciprocal translocation.

Karyotype analysis was performed on two blood cul- $\stackrel{\mathbb{D}}{\varrho}$ 


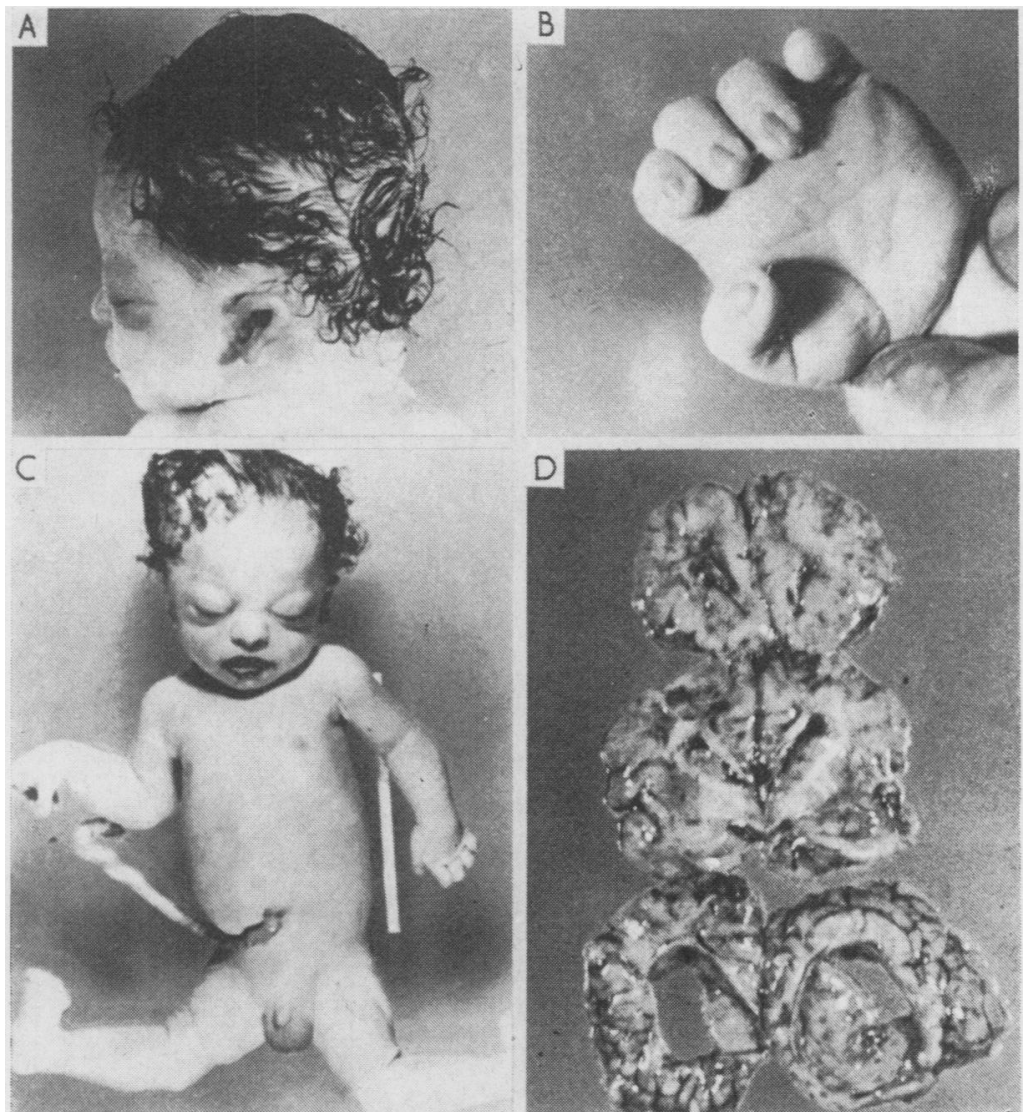

Fig. 1. Photographs of the propositus: (A) facies with malformed external ears and palpebral oedema, (B) hand with abnormal finger-nails and palmar simian crease, (C) infant at necropsy-note dislocation of both knees and ankles, (D) macroscopical sections of the brain showing communicating hydrocephaly.

tures from the phenotypically normal father. A modal number of 46 chromosomes was observed, and a structural alteration was established by studying 20 karyotypes from both cultures. The same type of long chromosome No. 2 seen in his son was present. In addition, one of the chromosomes of the group $\mathrm{C}$ was missing while an extra chromosome, morphologically similar to those of group D, was present (Fig. 3). These alterations can be interpreted as a balanced reciprocal translocation between the long arm of a chromosome No. 2 and the short arm of one group $\mathrm{C}$ chromosome; the long arm of No. 2 and the apparent extra $D$ being the two new chromosomes $2^{c}$ and $\mathrm{C}^{2}$ formed by the translocation (Fig. 4).

The two translocated chromosomes were measured and compared to the measurements of the chromosomes of group A and some chromosomes of group C. Chromosome measurements were made on photographic enlargements of 20 karyotypes, 10 from the propositus and 10 from the father, and the relative chromosome lengths were expressed as percentages of the haploid autosomal complement. The data are presented as a mean \pm one standard error (Table I). Differences of means were tested for statistical significance by the ttest and $p$ values were calculated.

The following relationships can be seen from the data:

(1) The sum of the total length of the two translocated chromosomes is equal ( $p=0.6)$ to the sum of the length of the normal chromosomes No. 2 and one chromosome C presumably classified as No. 8.

$$
\begin{aligned}
& 2^{c}(9 \cdot 82 \pm \cdot 12)+C^{2}(3.66 \pm \cdot 06)=13.48 \\
& 2(8 \cdot 46 \pm \cdot 14)+8 \quad(4.99 \pm \cdot 06)=13.45
\end{aligned}
$$

(2) No significant differences $(\mathrm{p}=0.4)$ exist between the short arm of $2^{c}$ and the short arm of No. 2, or between the long arm of $\mathrm{C}^{2}$ and the long arm of No. 8:

$$
\begin{aligned}
& 2^{\text {c }} \text { s.a. }(3 \cdot 20 \pm \cdot 05)=2 \text { s.a. }(3 \cdot 24 \pm \cdot 09) \\
& \mathrm{C}^{2} \text { l.a. }(3 \cdot 36 \pm \cdot 06)=8 \text { l.a. }(3 \cdot 44 \pm \cdot 05)
\end{aligned}
$$

(3) The long arm of $2^{c}$ is about equal $(p=0.50)$ to the sum of the long arm of No. 2 plus the short arm of No. 8 , less the short arm of $\mathrm{C}^{2}$ :

$$
\begin{aligned}
& 2 \text { 1.a. }(5 \cdot 22 \pm \cdot 09)+8 \text { s.a. }(1 \cdot 54 \pm \cdot 05)-C^{2} \text { s.a. }(0 \cdot 29 \pm \\
& \cdot 009)=6 \cdot 48 \\
& 2^{c} 1 . a .=6 \cdot 62 \pm \cdot 09 .
\end{aligned}
$$


These measurements and the above relationships suggest that the chromosome $\mathrm{C}$ involved in the translocation may be one chromosome 8 . We have classified as No. 8 the chromosome which appeared to be less metacentric than those considered as No. 7 and 11, and more metacentric than chromosomes 9 and 10 . Unfortunately, autoradiographic studies were not carried out. These, if combined with the measurements, might



FIg. 2. Metaphase and karyotype of propositus. Note that the long arm of one of the chromosomes No. 2 is significantly longer than the other member of this pair.

TABLE I

AVERAGE CHROMOSOME MEASUREMENTS^ FROM 20 CELLS: 10 FROM PROPOSITUS, 10 FROM FATHER

\begin{tabular}{|c|c|c|c|c|c|c|c|c|}
\hline \multirow{2}{*}{$\begin{array}{l}\text { Chromosome } \\
\text { No. }\end{array}$} & \multicolumn{4}{|c|}{ Father of Propositus } & \multicolumn{4}{|c|}{ Propositus } \\
\hline & Long Arm & Short Arm & Total Length & $\begin{array}{c}\text { Centromere } \\
\text { Index }\end{array}$ & Long Arm & Short Arm & Total Length & $\begin{array}{c}\text { Centromere } \\
\text { Index }\end{array}$ \\
\hline $\begin{array}{r}1 \\
2 \\
3 \\
8 \\
9 \\
10 \\
2^{\mathbf{c}} \\
\mathbf{C}^{2}\end{array}$ & $\begin{array}{l}4.49 \pm 0.04 \\
5.22 \pm 0.09 \\
3.69 \pm 0.06 \\
3.44 \pm 0.05 \\
3.25 \pm 0.06 \\
3.14 \pm 0.06 \\
6.62 \pm 0.09 \\
3.36 \pm 0.06\end{array}$ & $\begin{array}{l}4.48 \pm 0.09 \\
3.24 \pm 0.09 \\
3.38 \pm 0.05 \\
1.54 \pm 0.05 \\
1.38 \pm 0.02 \\
1.27 \pm 0.04 \\
3.20 \pm 0.05 \\
0.29 \pm 0.009\end{array}$ & $\begin{array}{l}8.98 \pm 0.13 \\
8.46 \pm 0.14 \\
7.08 \pm 0.08 \\
4.99 \pm 0.06 \\
4.60 \pm 0.06 \\
4.38 \pm 0.06 \\
9 \cdot 82 \pm 0.12 \\
3.66 \pm 0.06\end{array}$ & $\begin{array}{r}49.90 \\
38.32 \\
47 \cdot 74 \\
30.93 \\
30 \cdot 00 \\
28.99 \\
32.56 \\
7.92\end{array}$ & $\begin{array}{l}4.43 \pm 0.09 \\
5.04 \pm 0.09 \\
3.54 \pm 0.08 \\
3.26 \pm 0.04 \\
3.22 \pm 0.04 \\
3.19 \pm 0.06 \\
6.56 \pm 0.11\end{array}$ & $\begin{array}{l}4.33 \pm 0.09 \\
3.14 \pm 0.08 \\
3.36 \pm 0.10 \\
1.64 \pm 0.04 \\
1.40 \pm 0.06 \\
1.21 \pm 0.02 \\
3.24 \pm 0.06\end{array}$ & $\begin{array}{l}8 \cdot 76 \pm 0.21 \\
8 \cdot 19 \pm 0 \cdot 17 \\
6.91 \pm 0 \cdot 13 \\
4.91 \pm 0.06 \\
4 \cdot 63 \pm 0.03 \\
4 \cdot 42 \pm 0.06 \\
9 \cdot 81 \pm 0 \cdot 10\end{array}$ & $\begin{array}{l}49 \cdot 43 \\
38 \cdot 33 \\
48 \cdot 59 \\
31 \cdot 37 \\
30 \cdot 29 \\
27 \cdot 58 \\
33 \cdot 07\end{array}$ \\
\hline
\end{tabular}

* Mean values and standard errors of arm measurements expressed as percentages of haploid autosomal complement. 


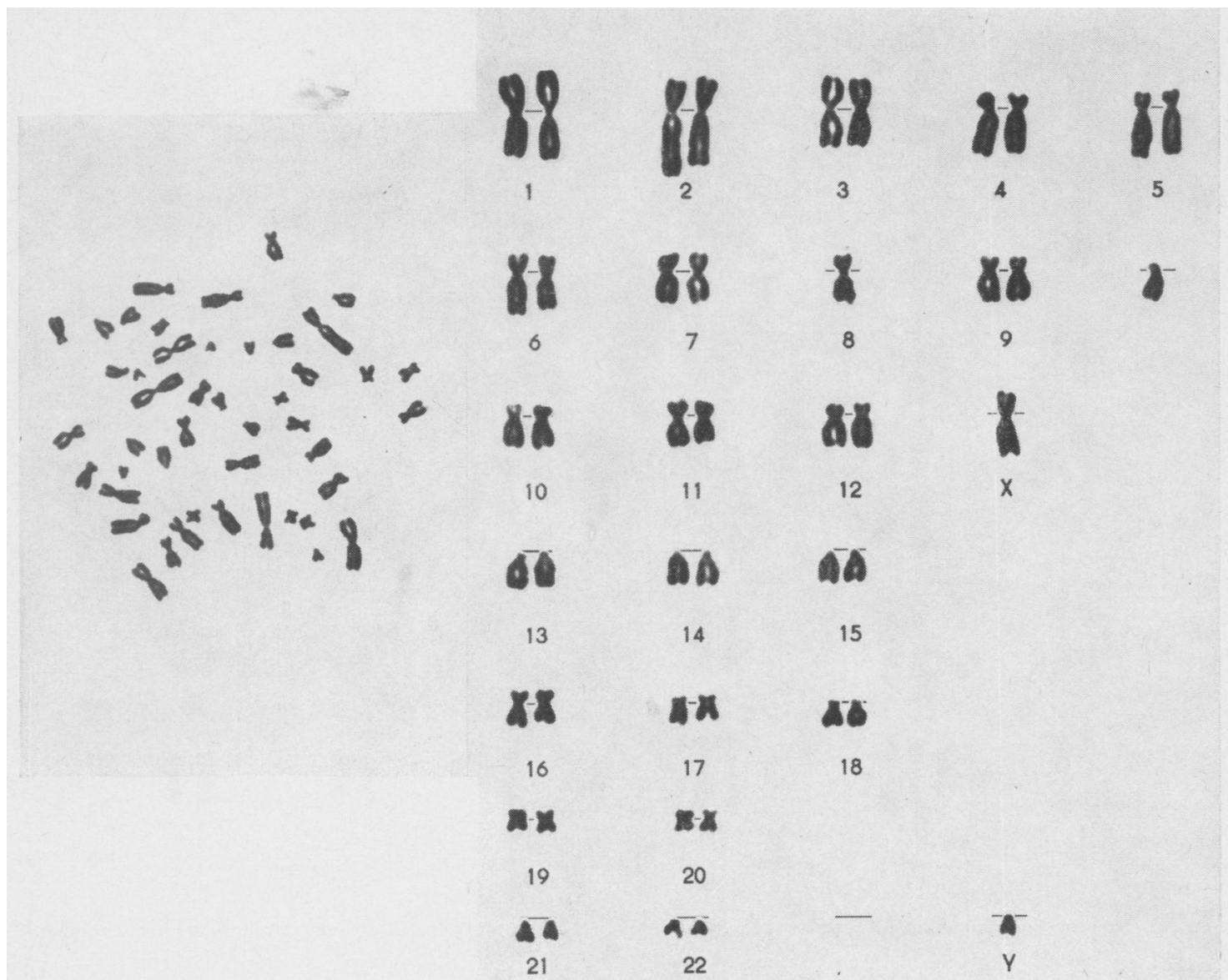

Fig. 3. Metaphase and karyotype of the father of the propositus. Note the long chromosome No. 2, the absence of one chromosome No. 8 , and the presence of one extra abnormal acrocentric.

provide a better identification of the chromosomes of group $\mathrm{C}$, as has been demonstrated by Giannelli and Howlett for groups D (1966) and E (1967).

Family Data. The proband was the product of the first pregnancy of phenotypically normal parents. Chromosome studies show that the father is the balanced carrier of the translocation and the mother is normal. The only sib of the father, a sister, is married, but she has had no children or abortions. Her karyotype is normal. The paternal grandparents are also phenotypically normal. No family history of abortions or malformations could be ascertained in other members of the family. Chromosome studies have not been performed on the paternal grandparents or other members of the family because of lack of co-operation.

\section{Discussion}

The genetic constitution in the progeny of a balanced translocation heterozygote depends on the meiotic segregation of four chromosomes: the two translocated chromosomes and their corresponding unaltered normal homologues. These chromosomes form a cross-shaped configuration (Fig. 5), during pairing at pachytene of the first meiotic division. The translocation here described is very asymmetrical, and the most likely configuration at metaphase 1 is a chain IV. Three kinds of segregation could occur: alternate, Adjacent I, and Adjacent II. The results observed in maize and drosophila have shown that the relative frequency of each type of segregation is related to the size of the interchanged segment and the length of the two 


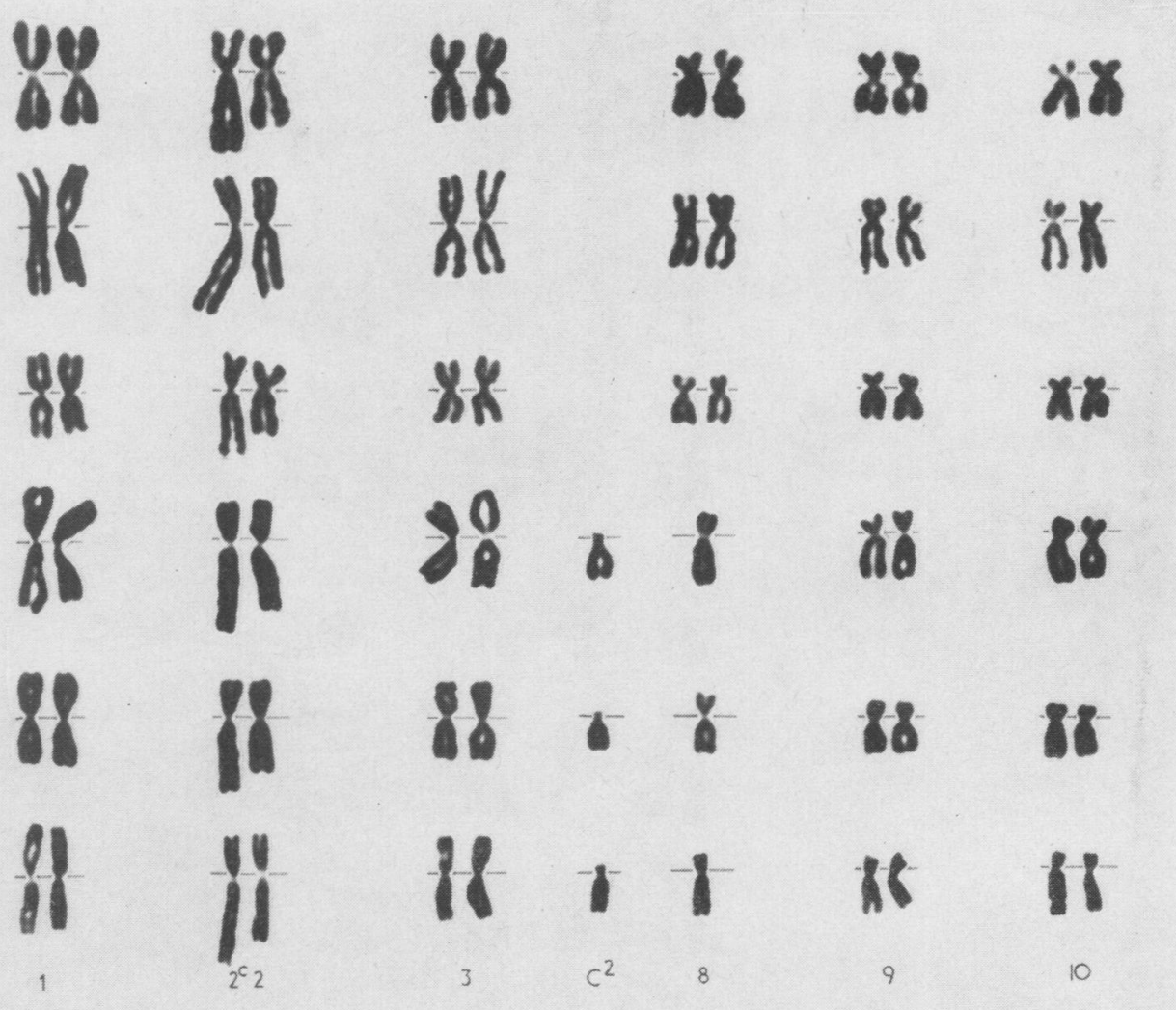

Fig. 4. Selected chromosomes from six cells. The top three rows are from the propositus; the bottom three rows are from the father.

chromosomes involved (Burnham, 1950, 1956, 1962). In our case, the two chromosomes affected are long and the translocated segments are relatively small. We would expect, therefore, that alternate segregation would be more frequent than Adjacent I, whereas the occurrence of type Adjacent II would be very low.

Six types of gametes may be formed by the three types of segregation. After fertilization, the combination of these gametes with normal ones would give rise to six kinds of zygotes, as shown in Table II. Two of these combinations involve duplication or deletion for the largest portion of a long autosome, No. 2, and both are known to be lethal in humans (Hall and Källén, 1964; Kelly et al., 1965; Kerr and Rashad, 1966). Furthermore, these two kinds would be derived from Adjacent II type of segregation which is expected to be infrequent in the present case. Therefore, four classes are likely to be found among the offspring of a balanced carrier such as the father of the propositus: the normal, the carrier, the deletion of the
TABLE II

GAMETES AND POSSIBLE ZYGOTES THAT WOULD BE FORMED BY EACH TYPE OF SEGREGATION

\begin{tabular}{|c|c|c|c|c|c|c|}
\hline & \multicolumn{6}{|c|}{ Zygotes } \\
\hline \multirow[t]{2}{*}{ Gametes } & \multicolumn{2}{|c|}{ Alternate } & & \multicolumn{2}{|c|}{ Adjacent } & \\
\hline & & $2^{c} \mathrm{C}^{2}$ & $2^{\mathrm{c} C}$ & $2 \mathrm{C}^{2}$ & $22^{c}$ & $\mathrm{CC}^{2}$ \\
\hline $2 \mathrm{C}$ & $\frac{2 \mathrm{C}}{2 \mathrm{C}}$ & $\frac{2^{c} C^{2}}{2 C}$ & $\frac{2^{c} \mathrm{C}}{2 \mathrm{C}}$ & $\frac{2 \mathrm{C}^{2}}{2 \mathrm{C}}$ & $\frac{22^{\mathrm{c}}}{2 \mathrm{C}}$ & $\frac{\mathrm{CC}^{2}}{2 \mathrm{C}}$ \\
\hline
\end{tabular}

$\star$ Proband.

small arm of one chromosome $\mathrm{C}$ with a small duplication of chromosome No. 2, and the duplication of the small arm of the chromosome $\mathrm{C}$ with a small deletion of the long arm of a No. 2. The last class was found in the propositus. The severity of the defects observed in this child suggests that the duplication here described might result in abortion, stillbirth, or neonatal death.

The clinical manifestations caused by the deletion of the short arm of chromosomes of the C 


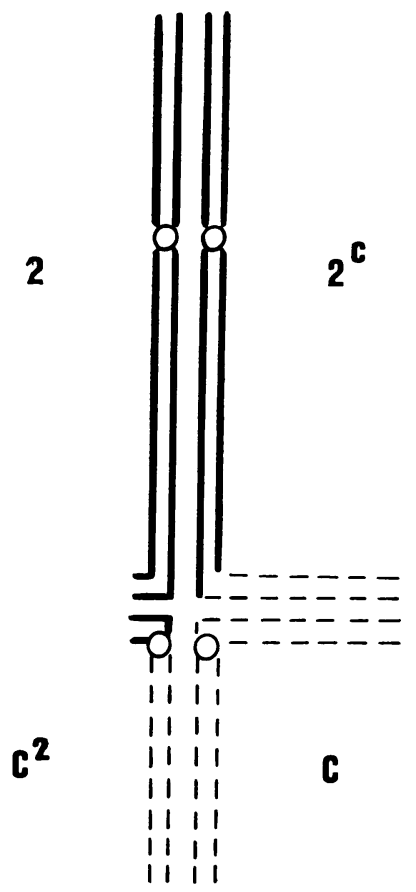

FIG. 5. Cross configuration in prophase of meiosis 1.

group are not known. Some of these deletions might be viable as are those for the short arm of chromosome No. 4 (Lejeune et al., 1963) or the short arm of chromosome 18 (de Grouchy, Bonnette, and Salmon, 1966). Others could be non-viable, causing embryonic or foetal death.

Though little information is available concerning the probability of survival of the duplication or the deletion for the short arm of the $\mathrm{C}$ chromosome involved in the present case, genetic counselling can be based on the proportion of different types of zygotic combinations expected from meiotic segregation. The anticipated risk for the balanced carrier of having abortions, stillbirths, or abnormal children would be as high as $50 \%$. Furthermore, half of the apparently normal children of a balanced carrier of the translocation would also be carriers of the translocation.

\section{Summary}

The unbalanced form of a reciprocal translocation $t(2 q+; C p-)$ was discovered in a stillborn with multiple malformations and partial trisomy for the short arm of one chromosome of group C, probably a No. 8. The major malformations observed were communicating hydrocephalus, premature ossification and fusion of cranial sutures, dislocation of both tibia anterior to the femoral condyles, and lateral dislocation of the ankles. The chromosomes involved in the translocation were identified visually and by measurements. The father was the carrier of the balanced form of the translocation. The meiotic behaviour of the translocated chromosomes and the genetic risk of the balanced carrier are discussed.

The authors thank Mrs. Carolyn Meiller for valuable technical assistance, and Mrs. Helen Carroll for help in the statistical evaluation of chromosome measurements. We are also most grateful to Dr. E. Chu for the review of the manuscript.

\section{REFERENCES}

Burnham, C. R. (1950). Chromosome segregation in translocations involving chromosome 6 in maize. Genetics, 35, 446.

- (1956). Chromosomal interchanges in plants. Bot. Rev., 22 419.

(1962). Interchanges. In Discussion in Cytogenetics, pp. 66116. Burgess Publishing Company, Minneapolis.

Chicago Conference-Standardization in Human Cytogenetics (1966). Birth Defects Original Article Series V. 11, 2.

de Grouchy, J., Bonnette, J., and Salmon, Ch. (1966). Délétion du bras court du chromosome 18. Ann. Génét., 9, 19.

- and Canet, J. (1965). Translocation 6-12 13-15 et trisomie partielle 6-12 probablement 10 . ibid., 8, 16.

, Roy, C., Lachance, R., Frezal, J., and Lamy, M. (1967a). Trisomie partielle $\mathrm{C}$ par translocation $\mathrm{t}(\mathrm{Cp}-; \mathbf{B q}+)$. Arch. franç. Pédiat., 24, 849.

, Thieffry, S., Aicardi, J., Chevrie, J. J., and Zucker, G. (1967b). Trisomie partielle $C$ par translocation $t(C q-; D p+)$ et remaniement d'un $\mathrm{C}(\mathrm{p}-\mathrm{q}+)$. ibid., 24, 859.

Edwards, J. H., Fraccaro, M., Davies, P., and Young, R. B. (1962). Structural heterozygosis in man: Analysis of two families. Ann. hum. Genet., 26, 163.

Giannelli, F., and Howlett, R. M. (1966). The identification of the chromosomes of the D group (13-15) Denver: an autoradiographic and measurements study. Cytogenetics, 5, 186.

, and - (1967). The identification of the chromosomes of the E group (16-18) Denver: an autoradiographic and measurement study. ibid., 6, 420.

Gray, J. E., Dartnall, J. A., Creery, R. D. G., and Croudace, J. (1966). Congenital anomalies due to transmission of a chromosome translocation. F. med. Genet., 3, 59 .

Hall, B., and Källén, B. (1964). Chromosome studies in abortuses and stillborn infants. Lancet, $1,110$.

Kelly, S., Almy, R., Jakovic, L., and Buckner, L. (1965). Autosomal monosomy in a spontaneous abortion. ibid., $1,166$.

Kerr, M., and Rashad, M. N. (1966). Chromosome studies on spontaneous abortions. Amer. F. Obstet. Gynec., 94, 322.

Lejeune, J., Berger, R., Rethoré, M. O., Salmon, Ch., and Kaplan, M. (1966). Translocation $C_{c} \sim F$ familiale déterminant une trisomie pour le bras court du chromosome 12. Ann. Génét., 9, 12.

, LaFourcade, J., Berger, R., Vialatte, J., Boeswillwald, M., Seringe, P., and Turpin, R. (1963). Trois cas de délétion partielle du bras court d'un chromosome 5. C.R. Acad. Sci. (Paris), 257, 3098.

Lindsten, J., Fraccaro, M., Klinger, H. P., and Zetterqvist, P. (1965). Meiotic and mitotic studies of a familial reciprocal translocation between two autosomes of group 6-12. Cytogenetics, 4, 45.

Lord, P. M., Casey, M. D., and Laurance, B. M. (1967). A new translocation between chromosomes in the 6-12 and 21-22 groups. f. med. Genet., 4, 169.

Moorhead, P. S., Nowell, P. C., Mellman, W. J., Battips, D. M., and Hungerford, D. A. (1960). Chromosome preparations of leukocytes cultured from human peripheral blood. Exp. Cell Res., 20, 613.

Punnett, H. H., Pinsky, L., Digeorge, A. M., and Gorlin, R. J. (1966). Familial reciprocal C/18 translocation. Amer. F. hum. Genet., 18, 572.

Rohde, R. A., and Catz, B. (1964). Maternal transmission of a new group-C (6/9) chromosomal syndrome. Lancet, 2, 838. 